\title{
ZMIZ1 Gene
}

National Cancer Institute

\section{Source}

National Cancer Institute. ZMIZ1 Gene. NCI Thesaurus. Code C119666.

This gene plays a role in androgen receptor-mediated gene expression. 